\title{
New Concepts of Fast Breeder Reprocessing
}

G. Koch

Institut für Heiße Chemie Projekt Wiederaufarbeitung und Abfallbehandlung

\section{Kernforschungszentrum Karlsruhe}





\section{KERNFORSCHUNGSZENTRUM KARLSRUHE}

Institut für Heisse Chemie

projekt Wiederaufarbeitung und Abfallbehandlung

KEK 3990

PWA $60 / 85$

New Concepts of Fast Breeder Reprocessing

Günter Koch

Sonderdruck aus:

Radiochimica Acta 37, 205-212(1984)

Kernforschungszentrum Karlsruhe GmbH, Karlsruhe 


\section{New Concepts of Fast Breeder Reprocessing* \\ By GUNTER KOCH, Institut für Heisse Chemie, Kernforschungszentrum Karlsruhe, P. O. B. 3640, D.7500 Karlsruhe, West Germany}

(Received January 29, 1985 ; revised March 25, 1985)

Fuel reprocessing / Fast breeder reactors / Uranium resources / Waste minimization/Off-gas purification

\section{Abstract}

The Fast Breeder Reactor (FBR) is unique with regard to fuel efficiency. While the Light-Water Reactor (LWR) consumes roughly 200 tons of natural uranium per gigawatt-year of electricity produced, the FBR has a demand of only 1.5 tons uranium per GWa. An improvement of fuel efficiency by a factor of more than 100 has never before been realized in the development of a technical system. Resources of uranium are limited and would be exhausted within two human generations if consumed by LWRs. In contrast, if burnt in FBRs they will provide a reliable source of energy for many human generations.

Chemical reprocessing of the nuclear fuel, and recycle of the energy carrier materials plutonium and uranium, is the key to achieve this outstanding efficiency. Based on the PUREX process which has proven successful in thermal fuel reprocessing, procedures and equipment have been developed to adapt this process to FBR fuel conditions, and to improve both its economy and environmental compatibility. This paper concentrates on the chemical aspects of these concepts; it discusses in particular the minimization of medium-active aqueous wastes by application of a 'salt-free' PUREX scheme in conjunction with electro-redox procedures, splitting and recycling of raffinate streams, improvements in fuel dissolution and off-gas purification, and the development of specialized construction materials. In addition, some guidelines to future R \& D will be discussed.

\section{Why the Fast Breeder?}

This question is answered by Figure 1 which compares the fuel efficiency of various nuclear reactor systems. To generate 1 gigawatt-year of electricity - roughly the annual production of a big $1300 \mathrm{MWe}$ power station - a light-water reactor (LWR) which is operated without fuel recycle consumes 205 tons of natural uranium. Little more than 1 ton is indeed fissioned to produce energy, while 204 tons, or 99,5\% of the material invested, would be wasted with this so-called "once-through" or "throwaway" type of fuel management. A particularly severe loss of material are the 168 tons of depleted uranium $80 \%$ of the uranium mined - which are produced during fuel enrichment and cannot be further used in the LWR.

The second line of Fig. 1 shows what happens when the radiochemist enters the scene. Chemical reprocessing of the spent fuel, and recycle of the recovered energy-carrier materials plutonium and uranium into the LWR, reduces its uranium consumption by roughly $40 \%$, to 120 tons per gigawatt-year. However there is still a loss of 107 tons of depleted uranium which remains a waste material for the LWR.

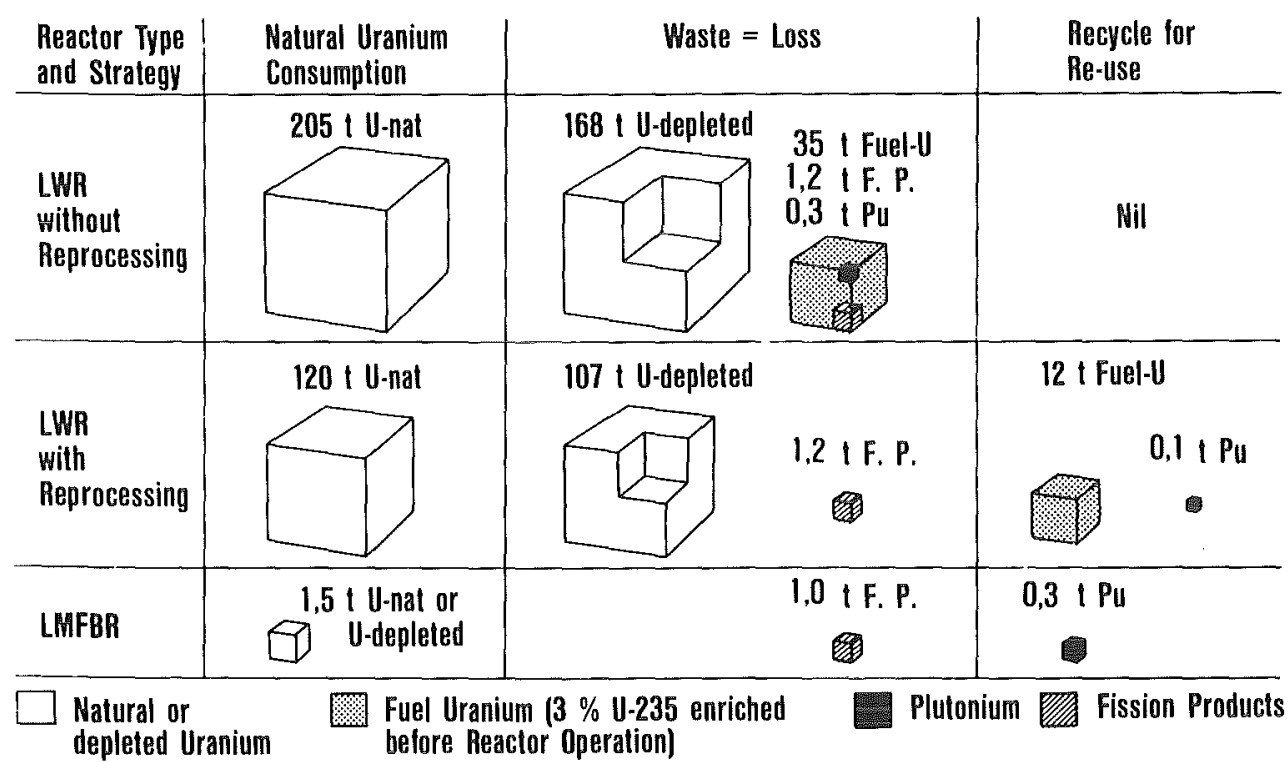

Fig. 1. Uranium consumption for the generation of 1 gigawatt-year of electricity by light-water reactors (with and without fuel recycle) and by fast breeder reactors. Based on figures elaborated in the course of the International Nuclear Fuel Cycle Evaluation (INFCE) program, IAEA, Vienna 1980

* Invited Paper presented at the International Conference on Nuclear and Radiochemistry, Lindau, Oct. $8-12,1984$ 
The situation changes fundamentally when the energy carriers are recycled into the Fast Breeder Reactor (FBR) which consumes as little as 1.5 tons of natural uranium for the production of 1 gigawatt-year of electricity (line 3 of Fig. 1). Moreover the natural uranium can be substituted by depleted uranium which is available in vast amounts due to the earlier operation of light-water and similar thermal power reactors. The breeding gain of roughly $300 \mathrm{~kg}$ of plutonium per gigawatt-year can be accumulated for the start-up of additional power stations. The only waste which this reactor generates, except for unavoidable processing losses, are the fission products. The improvement of fuel efficiency, as compared against the LWR with throw-away fuel management, is a factor of more than 100 .

Next, let us consider the medium- and long-term uranium resource situation since the present oversupplies of uranium are often taken as an argument that fuel efficiency is not important. The most recent edition of the well-known "Red Book" [1] lists for the Western world a total of 4.3 million tons of "reasonably assured" and "estimated additional" uranium resources at production costs of up to 130 dollars per kilogram. (Present production costs are still in the range of 40-50 dollars per $\mathrm{kg}$ uranium.) Using the data given in Fig. 1, and assuming a 30-years operating lifetime of a nuclear power station, one easily estimates that these 4.3 million tons would just suffice to fuel a total of 700 of those $1300 \mathrm{MWe}$ throw-away LWRs. The equivalent of roughly 150 of such power stations is already operating today. This simple rule-of-thumb calculation confirms the results of more detailed scenarios which all conclude that even with a very moderate employment of nuclear energy, the known uranium resources would be exhausted within less than 50 years if consumed with LWRs [2]. In contrast, if utilized to fuel FBRs they will suffice to satisfy the world's energy needs for several millenia.

The problem is that electricity generated by FBRs is more expensive than that produced by LWRs as long as uranium is abundant and therefore cheap. The present situation is in some regard similar to the oil/coal relation some twenty years ago. A careful French analysis [3] has indicated that under comparable conditions of technological advancement, a cost advantage of roughly $15 \%$ will remain for the LWR under present uranium price conditions. Two conclusions can be drawn from this analysis:

(1) Already today, power generation by commercial-size fast breeder reactors would be cheaper than that by hardcoal power stations, under mid-European conditions.

(2) In consequence, the true competitor against the FBR is the LWR. In order to promote an early introduction of the resource-saving FBR, it is important to increase its economic competitivity - in other words, to decrease the cost of this reactor and its fuel cycle.

\section{Chemical treatment of FBR fuel elements}

\subsection{General}

FBR fuel reprocessing is closely similar to LWR fuel reprocessing, and has thus a reliable technological basis in earlier LWR reprocessing experience. A wide variety of processes, both aqueous and non-aqueous, both high- and low-decontamination varieties, have been extensively studied in the past [4]. Of those developed to the plant scale the PUREX process, based on solvent extraction with tributyl phosphate (TBP), has been found to be superior, and this view is accepted worldwide since all industrial fuel reprocessing plants operating today are based on this process.

Figure 2 outlines some of the major differences between irradiated FBR and LWR fuel elements. The main effects which must be accounted for in FBR reprocessing are

- a roughly 10 -fold plutonium concentration,

- a roughly 10 -fold increase of specific radioactivity, due to a slightly higher average burn-up but in particular to a distinctly lower cooling time.

- and a quite different fuel element design and reactor coolant, which both affect mostly the mechanical han-
FBR

$\begin{array}{ll}\text { Fuel } & (\mathrm{U}, \mathrm{Pu}) \mathrm{O}_{2} \text { ("MOX") } \\ \text { Pu Concentration } & \text { CORE: } 15-30 \% \mathrm{Pu} \\ & \mathrm{MIX}^{*}: 8-15 \% \mathrm{Pu} \\ \text { Burnup } & \text { CORE: } 70000-100000 \mathrm{MWd} / \mathrm{t} \\ & \mathrm{MIX}^{*}: 40000-55000 \mathrm{MWd} / \mathrm{t} \\ \text { Cooling } & 1 \text { year } \\ \text { Specific Radioactivity } & \text { CORE: } 10 \mathrm{MCi} / \mathrm{t} \\ & \text { MIX*: } 5 \mathrm{MCi} / \mathrm{t} \\ \text { Fission } & \text { Pu-239/241, Fast Flux } \\ \text { Fuel Element } & \text { Wrapper } \\ \text { Coolant } & \mathrm{Na}\end{array}$

$\frac{\mathrm{LWR}}{\mathrm{UO}_{2}}$
$1 \% \mathrm{Pu}$
$35000 \mathrm{MWd} / \mathrm{t}$
$3-7$ years
$1 \mathrm{MCi} / \mathrm{t}(3 \mathrm{a}$ cooled $)$
$0.5 \mathrm{MCi} / \mathrm{t}$ (7a cooled)
$\mathrm{U}-235, \mathrm{Thermal}$ Flux
$\mathrm{No}$ Wrapper
$\mathrm{H}_{2} \mathrm{O}$

* MIX $=$ Core + Axial Blanket Mixture 
dling and treatment procedures before the chemical process takes place.

These effects require that both the chemical flowsheets and the equipment must be adapted accordingly. Moreover it appeared that innovations which could simplify the process, and minimize its releases, would be highly desirable. The research which has been carried out to make and to demonstrate these adaptations and improvements, has created a variety of new techniques which form the basis of an advanced FBR reprocessing plant concept for which the name "MILLI-II" was chosen $[5,6]$. Taking into account that only limited amounts of irradiated FBR fuel will become available in the next decade in West Germany, i. e. roughly 6 tons per year from the 300 MWe prototype power station at Kalkar plus 0.5 tons per year from the experimental 20 MWe KNK-II at Karlsruhe, it was proposed to demonstrate this concept in a small pilot plant of $50 \mathrm{~kg} \mathrm{U}+\mathrm{Pu}$ per day capacity. However, the concept is not dependent on throughput, and could be scaled up if desired. The following discussion will concentrate on the chemical aspects of this concept.

\subsection{Minimization of PUREX process wastes}

One possibility of reducing the cost of reprocessing was found in a minimization of the medium-active liquid wastes because further processing and storage of these is expensive. In consequence, procedures have been developed by which the PUREX raffinate streams can be widely recycled, while the radioactivity fraction is concentrated to a small volume which is then combined with the liquid high-level waste.

The basis of these procedures is the application of electro-redox reactions instead of chemical reagents in the partitioning and back-extraction of plutonium [7]. In these steps, tetravalent plutonium extracted into the TBP phase is selectively backwashed into an aqueous phase, and separated from uranium, by reducing it to the non-extractable three-valent state in suitably designed equipment which combines the operations of countercurrent liquid-liquid extraction and of continuous cathodic reduction. Sketches of an electro-reduction pulse column and of an electro-reduction mixer-settler are presented in Figures 3 and 4 . Threevalent plutonium in the aqueous product solution from such a process must be re-oxidized to the extractable +4 state for additional purification or concentration operations, and this is readily performed in a continuous "ROXI" electro-oxidation flow cell (Figure 5). The hydrazonium ion which was used as a scavenger of nitrous acid in the preceding reduction process, is at the same time decomposed into water and nitrogen by electro-oxidation. After extraction of the plutonium in a subsequent purification cycle, the resulting aqueous raffinate is therefore practically free of any salt burden, and can readily be evaporated down to a very small concentrate volume of radioactive waste while the



Fig. 3. Electro-reduction puised column for continuous in-line reduction of plutonium in a liquid-liquid extraction system [7]

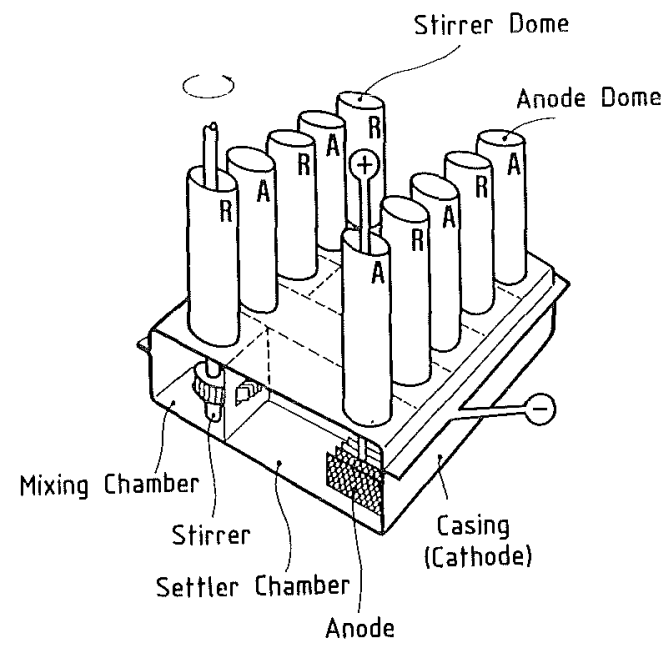

Fig. 4. Scheme of an electro-reduction mixer-settler

low-activity distillates can be widely recycled into the process.

This "raffinate recycle" is outlined in some more detail in Figure 6 which shows a very simplified scheme of the aqueous streams of the MILLI-II solvent extraction process. The high-activity raffinate of the first extraction cycle is routed into a two-stage high-level waste evaporator $(1 \mathrm{~W})$, and the medium-active raffinates from the plutonium and uranium purification cycles into a two- 


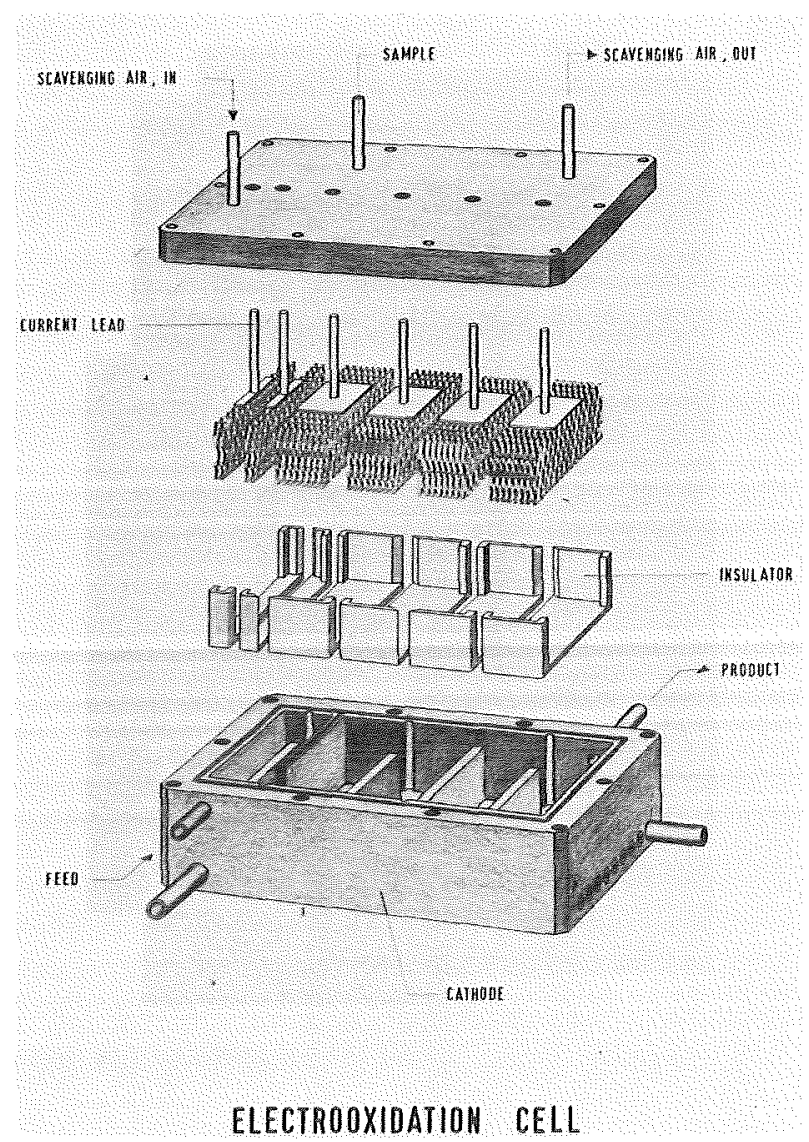

Fig. 5. Electro-reoxidation flow cell (ROXI) for continuous reoxidation of plutonium(III) and hydrazonium ions between extraction cycles [7]

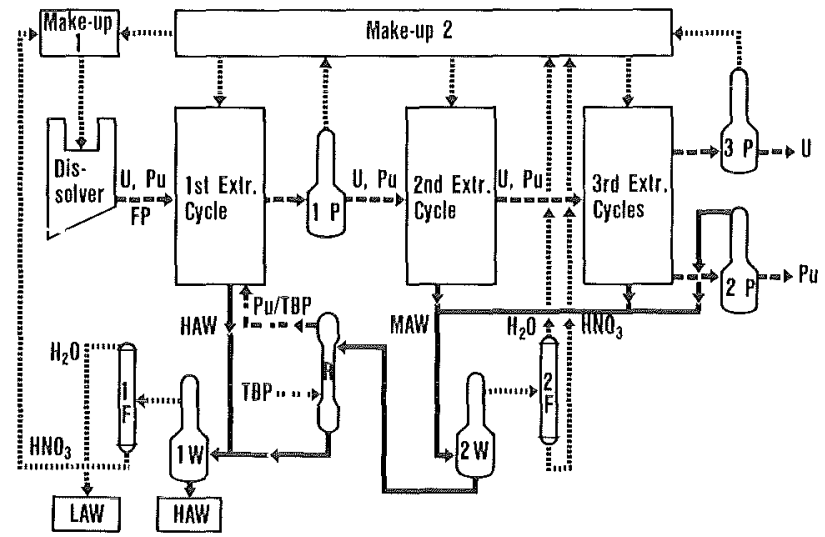

I.ig. 6. Raffinate recycle in the MILLI-II PUREX process

stage medium-level waste evaporator $(2 \mathrm{~W})$. The vapors from the two evaporators are fractionated in fractionator columns ( $1 \mathrm{~F}$ and $2 \mathrm{~F}$ ), and the recovered acid and most of the water are recycled into the process via the lowlevel make-up No. 2 and the medium-level make-up No. 1, respectively. The $2 \mathrm{~W}$ evaporator concentrate is routed into the $1 \mathrm{~W}$ high-level evaporator for further concentration, but prior to this any plutonium contained in the $2 \mathrm{~W}$ concentrate is recovered in a so-called rework ( $R$ ) column by solvent extraction with a small TBP stream which is then recycled into the first extraction cycle. Thus, the only aqueous waste streams leaving this arrangement of
PUREX cycles are the high-level waste concentrate and the low-level excess water but the medium-level aqueous raffinate wastes have been eliminated; in addition, a very careful recovery of valuable plutonium is provided by application of the $\mathrm{R}$ column.

Another process which is responsible for large volumes of salt wastes is the spent solvent regeneration which in the classic PUREX process is performed by sodium carbonate solution. This washing agent removes acidic TBP radiolysis products, like dibutylphosphoric acid, and the carbonate anion complexes metallic impurities like uranyl and plutonium (IV) ions to keep them soluble. However most of the soda is converted by traces of nitric acid into sodium nitrate, thus forming a tremendous salt burden in the medium-active spent solvent wash liquor.

This waste problem was solved by introducing hydrazonium carbonate as the washing agent for spent TBP solvent, and demonstration that its washing action is equivalent to that of sodium carbonate [7]. The hydrazonium nitrate which is formed as the main product in the spent washing agent is then decomposed into water, nitrogen, and nitric acid by electro-oxidation in a ROXI flow cell. The resulting medium-active waste solution which is practically salt-free is evaporated down to a small volume of radioactive concentrate which is routed into the highlevel waste system while the distillate is a low-level waste which is treated accordingly.

In consequence, the MILLI-II PUREX process will not produce any medium-level aqueous waste during normal operation. The electro-redox processes which are the key for this achievement, have undergone a very satisfactory industrial test in the WAK reprocessing plant at Karlsruhe. Both an electro-mixer-settler and a ROXI flow cell were installed into the second WAK plutonium cycle in 1979. Since that time, more than $400 \mathrm{~kg}$ of plutonium have been processed through this equipment; the operating experience was so good that another electro-mixer-settler is presently being installed into the high-activity extraction cycle of the WAK. In addition, an electro-pulsecolumn and two ROXI cells of MILLI-II dimensions are operating with good success in a large plutonium test cycle (PUTE) at Heisse Chemie in Karlsruhe since 1982. To date, $270 \mathrm{~kg}$ plutonium have been cycled through this equipment in only three test campaigns.

\subsection{Improvements in the chemical head-end}

The chemical head-end which precedes the PUREX process is schematically outlined in Figure 7. The fuel is dissolved with nitric acid and the solution must be clarified and adjusted before it goes to solvent extraction. The offgas must be purified from radioactive components which are released when the solid fuel structure is dissolved.

The dissolution behaviour of plutonium-uranium mixed-oxide (MOX) fuels is somewhat complicated, but can be understood on the basis of mechanistic studies of the pure metal dioxides which have recently been carried 


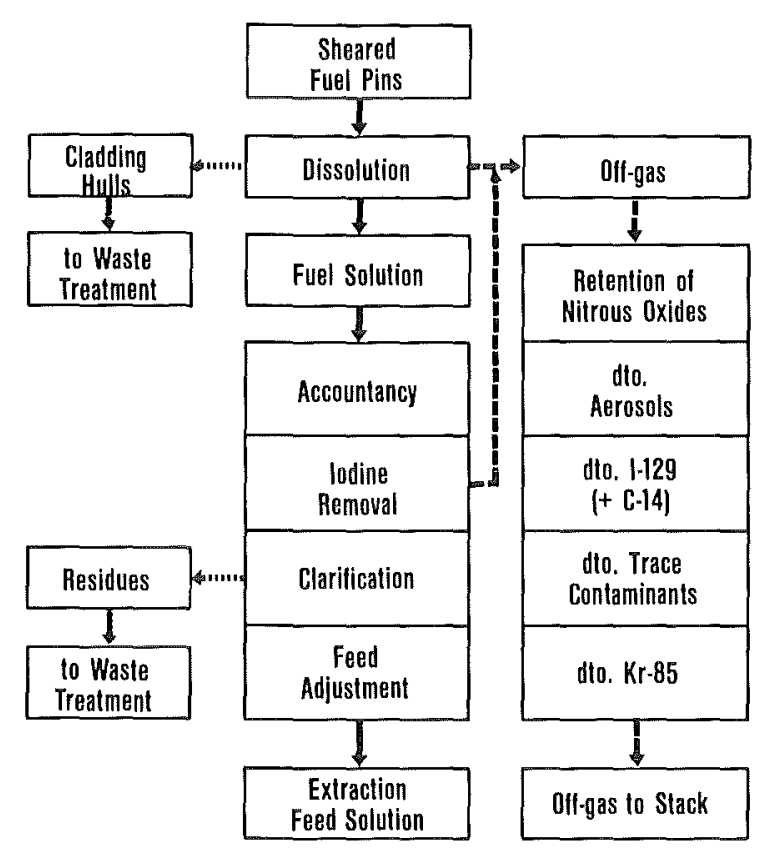

Fig. 7. Schematic outline of chemical head-end operations

out $[8-10]$. Uranium dioxide dissolves readily in nitric acid because the $\mathrm{U}^{4+}$ ion is oxidized to $\mathrm{UO}_{2}^{2+}$ in the crystal surface by nitrous acid (or a species in equilibrium with nitrous acid), before the $\mathrm{UO}_{2}^{2+}$ ion is released from the fluorite-type $\mathrm{UO}_{2}$ lattice [8]. Plutonium dioxide cannot be oxidized by nitric or nitrous acid and is therefore virtually insoluble; however it can be oxidized and dissolved in the presence of a strong oxidant [11]. Mixed crystals of $(\mathrm{U}, \mathrm{Pu}) \mathrm{O}_{2}$ show a transition from good solubility in nitric acid at low Pu concentrations to insolubility at high $\mathrm{Pu}$ concentrations; the dissolution rate remains "reasonably fast" for practical purposes as long as the $\mathrm{Pu}$ concentration is below roughly $40 \%$ of total metals. Consequently, conditions must be avoided in the fuel to be dissolved where mixed crystals with more than $40 \%$ plutonium, or even crystals of pure $\mathrm{PuO}_{2}$, can exist.

The key for meeting this requirement is a proper fuel production process. Starting from powder mixtures of the pure oxides, a particle size of less than $10 \mu \mathrm{m}$ is required in order that the sintering process will result in a more or less homogeneous solid solution [12]. Fuel pellets produced from normal coarse-grain oxide powders are therefore not satisfactory. Good qualities of mixed. oxide fuels are produced by coprecipitation, such as the Ammonium Uranyl Plutonyl Carbonate or AUPUC Process of the Alkem [12]. Other successful routes are the gel process developed in Britain [13] and elsewhere, and the Japanese microwave conversion process [14].

During reactor operation, plutonium is known to enrich at the hot central channel of the MOX pellet. The mechanisme of this effect is well understood [15]. It may result in plutonium concentrations of $>40 \% \mathrm{Pu}$ if MOX fuel with an original plutonium enrichment of more than roughly $25 \%$ is applied, that means, in small breeder reactors, but not in commercial ones with a plutonium enrichment of roughly $15 \%$. Moreover the effect can be controlled by a slightly substoichiometric fuel oxide composition.

As a résumé, we can predict that insoluble plutonium residues will not present a waste or loss problem in commercial FBR reprocessing. However they may present a problem in early pilot plants which have to cope with fuel elements which were not designed for a good solubility. For the dissolution of plutonium oxide residues, $\mathrm{HNO}_{3}$ containing a strong oxidant, mixtures of $\mathrm{HNO}_{3}-\mathrm{HF}$, or high-pressure dissolution with $\mathrm{HNO}_{3}$ are the candidate processes.

Iodine must be effectively removed from the dissolver solution before it goes to solvent extraction. Otherwise it would "smear" over practically all process streams, with the consequence of complicated and expensive retention systems for all plant off-gas streams. Experience shows that a few percent of the iodine may be retained in the dissolver solution because oxidation to non-volatile iodic acid can occur when the generation of nitrous oxides ceases towards the end of the dissolution [16]. As a remedy, nitrous oxides are then blown into the dissolver which reduce the iodic acid to volatile elemental iodine, and this treatment can be supported by isotopic dilution with inactive iodate. Trial operations with pilot-plantsize equipment have demonstrated that iodine is thus removed from the fuel solution to less than $0.1 \%$ [16].

\subsection{Dissolver off-gass purification}

The design of an optimized dissolver off-gas purification system is difficult due to the large number of parame ters involved, as e.g. composition and flow rate of the off-gas, type of mechanical head-end, dissolution management, and components to be removed [17]. A minimization of the off-gas flow-rate will facilitate the removal of trace contaminants; this general chemical rule is simply a consequence of the mass-action law.

Of the volatile radioactive species, iodine and aerosols must be effectively retained in order to meet with regulations. For ${ }^{129} \mathrm{I}$ a retention factor of a few hundred is required, depending on the plant size and on regulatory requirements. This figure would increase drastically if very short-cooled fuel would be processed because of the short-lived ${ }^{131} \mathrm{I}$; the technical and economic burden which would be imposed on to the off-gas purification system is in fact a major argument against decreasing the fuel cooling time below half a year.

Tritium is a rare example where FBR reprocessing offers less of a problem than the LWR case, because more than $90 \%$, and probably close to $99 \%$ of the tritium, escape from the fuel element during reactor operation. Scrubbing with tritium-free acid in the first PUREX cycle will reject the tritiated water to the high-level waste.

The need to retain ${ }^{85} \mathrm{Kr}$ is questionable; a recent cost/risk analysis [18] indicates that, from the radiologic standpoint, there is little justification for krypton retention as long as the number of reprocessing plants word- 


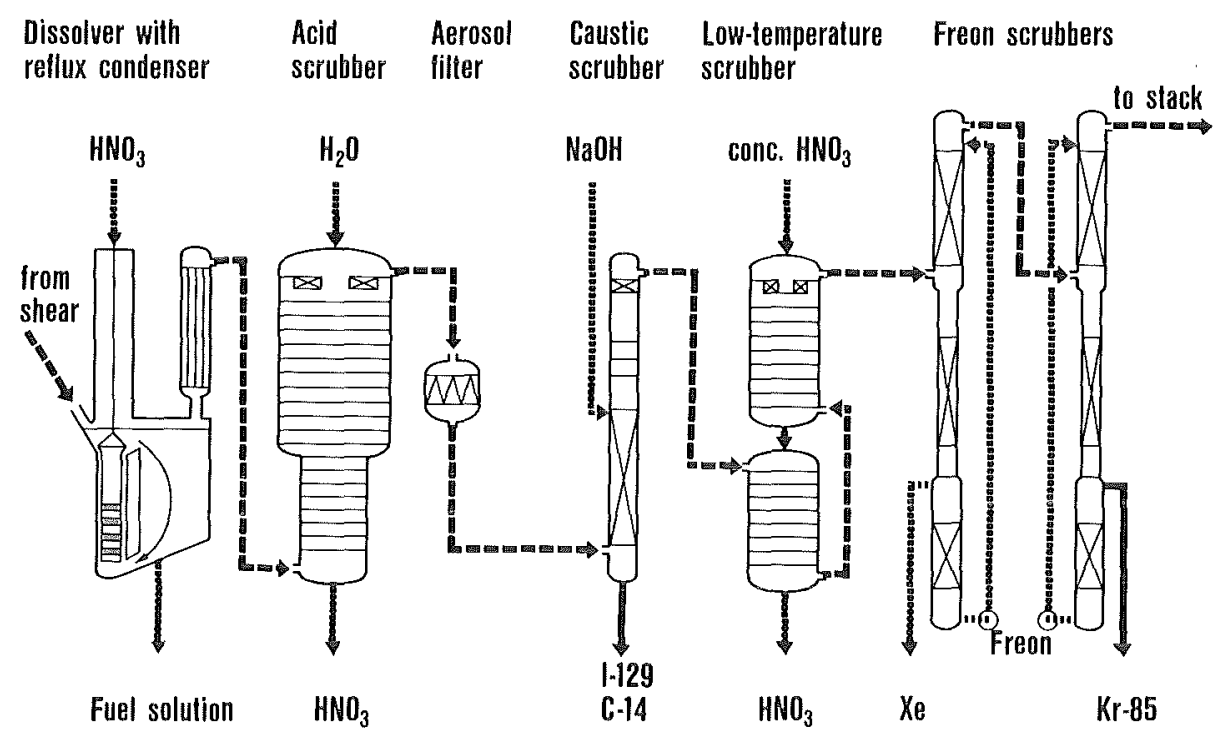

Fig. 8. Process scheme of the conceptual MILLI-II dissolver off-gas purification system

wide is small. The same applies, with even more emphasis, to ${ }^{14} \mathrm{C}$ which during dissolution is released as carbon dioxide. Nevertheless our concept includes krypton and ${ }^{14} \mathrm{C}$ retention, simply because we have the technology available and propose to demonstrate it.

Figure 8 shows a process scheme of the proposed MILLI-II dissolver off-gas purification system. The gas stream passes first through an acid washer for removal of nitrous oxides. Flow ratios and temperatures are chosen in such a way that more than $98 \%$ of the iodine pass through the washer while less than $2 \%$ are condensed in the acid stream which is recycled to becone part of a subsequent batch of dissolver acid. The off-gas stream leaving from the acid washer is then passed through a series of filters to remove aerosols. Next, most of the iodine is removed by sodium hydroxide solution in a caustic washer; carbon-14 dioxide is absorbed at the same time. The off-gas then passes through a low-temperature scrubber where cold, super-azeotropic nitric acid serves to scavenge any low-boiling contaminants, including traces of iodine, which might give rise to problems in the final krypton/xenon retention unit. Removal and purification of the two noble gases is performed by absorption in dichloro difluoro methane, better known as "Refrigerant R-12" or "Freon-12" [19].

A few comments on the reasons of this choice of system would probably not come amiss. First of all, we have decided in favour of a reduced-flow off-gas system to improve and facilitate the retention of contaminants. Second, our system includes a krypton retention process at the end of the purification line, and this necessitates an effective "scavenging" procedure from any gas components which might freeze out in the krypton/xenon absorption columns. As a consequence, it was possible to select a quite primitive - and cheap - process for iodine retention, i. e. a caustic soda scrub, which has the additional benefit of retaining the ${ }^{14} \mathrm{CO}_{2}$ as well. Such a choice would not have been possible with a high-flow off- gas system because nitrous fumes would be much less effectively retained in the acid washer, and the sodium hydroxide wash liquor in the caustic scrubber would be rapidly consumed. It would also not have been possible without the existence of a subsequent "scavenging" process, in the form of a low-temperature scrub with superazeotropic nitric acid, which will retain any traces of elemental iodine or iodine compounds escaping from the caustic washer.

\subsection{Specialized materials of construction}

Another field where improvements seemed desirable is that of construction materials. Stainless steel is the standard material for reprocessing equipment, but special procedures and conditions have called for specialized materials.

Titanium is applied for cathodes of electro-redox equipment. Since the casing of electro-mixer-settlers, and both the column tubes and sieveplates of electropulse-columns, serve as the cathodes at the same time, these pieces are made of titanium. For anodes, platinized titanium is normally applied. In addition, titanium may be used in the manufacture of evaporators, in particular those for plutonium.

Titanium is certainly not too exciting since this material is widely used in the chemical industry today. Less conventional is the application of platinized tantalum for ROXI anodes. Due to its extremely good corrosion resistance against hot nitric acid, tantalum might be considered for other sensible equipment as well, although the material price and cost of manufacture are a major obstacle.

Hafnium which was introduced by SCHMIEDER and collaborators [20] as a nuclear construction material some years ago, is obviously a quite unusial material indeed. Its neutron absorption cross-section of roughly 100 barn makes it an effective neutron absorber for criticality con. 
trol. Investigations of the corrosion behaviour had the unexpected result that hafnium is even more corrosion resistant under PUREX conditions than titanium or zirconium; corrosion rates as low as $1 \mu \mathrm{m} / \mathrm{a}$ can be expected $[20,21]$. Hafnium can thus be applied for the design of criticality-safe equipment for high plutonium throughput. The casing of one of the ROXI cells installed in the PUTE facility has been manufactured from hafnium. Other examples are hafnium sieve-plates for pulsed columns, or even plutonium product evaporators and fuel dissolver baskets for which the application of hafnium is being considered.

\section{Some guidelines to future R \& D}

It has been emphasized before that a decrease of FBR reprocessing costs is an important goal of research and development. Obviously, a major decrease of plant construction costs would require that the quantity of equipment, and consequently the volume of hot-cell space and building structure, be sensibly decreased. This means in turn to decrease the quantity of chemical operations and to reduce specific process volumes wherever possible.

A good example of such a development is the "saltfree PUREX" concept discussed in chap. 2.2 of this paper. The application of electro-redox procedures results in a size reduction of some of the PUREX equipment itself but its special merits lie in its potential to decrease considerably the equipment and space requirements for medium-level waste treatment, storage, and disposal.

Turning now to unsolved tasks which the radiochemist might be able to solve, a striking and annoying feature in the reprocessing of high-burnup, short-cooled nuclear fuels is the need of three cycles of solvent extraction for each of the products to meet specifications. New ideas how this luxury might be diminished have recently been discussed by SCHMIEDER and by HENRICH and their collaborators.

SCHMIEDER's approach [22] is to improve the efficiency of the solvent extraction process itself. This would involve a specific tayloring of the scrub conditions for removal of ruthenium and zirconium which are the "limiting" contaminants with short-cooled fuels. One of the measures considered is a very high saturation of the organic phase with uranium and plutonium, with the necessity to recycle the scrub stream into the feed stage of the first extraction column to prevent plutonium losses. Such a flowsheet will obviously require a sophisticated design and a very careful control during operation, which would be practically impossible without a reliable computer model, but fortunately we do have such a model with GEORG PETRICH's VISCO program [23]. In addition, improvements of metering and solvent extraction equipment will have to be made.

HENRICH's approach [24] is different. He proposes to replace part of the liquid-liquid separation stages by a solid-liquid separation process, specifically by freeze-crys- tallisation of uranyl or plutonyl nitrate hexahydrate from semi-concentrated nitric acid. Freeze-crystallisation in agitated reactors is a standard operation which is widely applied in the chemical industry today. When applied for uranium-plutonium purification, the mother liquors which contain appreciable concentrations of the products must be recycled, for instance into an early PUREX solvent extraction cycle which would form a first purification and product collection stage. Obviously the fission products will be recycled as well, and consequently no mediumactive liquid waste will be produced in such a combined process. Due to the high product concentration involved in a crystallisation process, specific equipment volumes should be fairly small in comparison with PUREX equipment. Another promissing feature is that the purified products, uranyl and plutonyl nitrate hexahydrate, could be directly converted into the pure or mixed oxides, for instance by a microwave process.

In spite of the importance of process economy, we should not loose out of sight improvements in regard to environmental compatibility and to resource utilisation. To give just one example of an open task in the latter field: It seems that the potential of the high-level waste as a materials source has scarcely been explored to date. Most attention in the past has been devoted to the isolation of radio-isotopes for application as radiation sources, while the recovery of valuable non-radioactive fission products has found little interest. However a recent study on the economic feasibility of recovering the noble metals fission products $(\mathrm{Pd}, \mathrm{Ru}, \mathrm{Rh})$ and $\mathrm{Tc}$ came out quite favourably [25]; the feed clarification residues from FBR fuel dissolution which contain a major percentage of the noble metal fission products [26] could be a valuable raw material if cheap and reliable recovery routes were established.

\section{Conclusions}

As a summary, the following conclusions may be drawn: The reprocessing of fast breeder fuel elements is technically feasible. Modifications to adapt the PUREX process to the specific FBR conditions have been successfully demonstrated in experimental facilities. New concepts have been developed to improve the economy, reliability, and safety of the process. Techniques for the minimization of radioactive wastes have been elaborated. Potential improvements are under study. The basic technology is available for demonstration in an advanced demonstration plant.

\section{References}

1. Uranium: Resources, Production and Demand. Prepared by OECD and IAEA. Paris - Vienna 1983.

2. See, e.g., BECKURTS, K. H., CONOLLY, T. J., HANSEN, U., JAEK, W.: Nuclear Energy Futures, 11 th World Energy Conference, Munich 1980, Vol. 4 B, p. 239. 
3. BAUMIER, J, DUCHATELLE, L: The case of developing the LMFBR in France, in: The Economics of Nuclear Energy (ed. L. G. BROOKES, H. MOTAMEN), Chapman \& Hall, London - New York 1984.

4. For reviews see, e.g., G. KOCH (ed.): Transuranium Elements, Vol. A1, II, Chap. 5,1 and 5.2, p. 177-265. Gmelin Handbook of Inorganic Chemistry, Springer, Berlin-Heidelberg - New York 1974.

5. KOCH, G., GOLDACKER, H., HAUG, H., HENRICH, E. OCHSENFELD, W., SCHMIEDER, H., BÖHME, G., KÖHLER, W., GRIMM, L.: "MILLI-II: Konzeptstudie einer Pilotanlage zur Wiederaufarbeitung von Schnellbrüter-Brennelementen", KFK-Nachr. 15, 158 (1983).

6. KOCH, G., BÖHME, G.: "Anlagenkonzept und Erfahrungsbasis für die Schnellbrüter-Wiederaufarbeitung", German Report KFK-3740 (1984), p. $102-127$.

7. SCHMIEDER, H., GOLDACKER, H.: "Die Karlsruher ElektroRedoxverfahren: von der Entwicklung zum technischen Einsatz", German Report KFK-3740 (1984), p. $207-226$.

8. HERRMANN, B.: "Auflösung unbestrahlter $\mathrm{UO}_{2}$-Pellets in Salpetersäure", German Report KFK-3673 (1983).

9. GREILING, H. D., LiESER, K. H.: "Properties of $\mathrm{ThO}_{2}$, $\mathrm{UO}_{2}$, and $\mathrm{PuO}_{2}$ as function of pretreatment and their dissolution in $\mathrm{HNO}_{3}$ ", Radiochim. Acta 35, 79 (1984).

10. BAUMG ÄRTNER, F., BRÜCKL, N., LUCKNER, N., KIM, J. I., KANELLAKOPULOS, B.: "Dissolution of $\mathrm{PuO}_{2}$ in $\mathrm{HNO}_{3}$ solutions: Thermodynamic and kinetic study of dissolution mechanisms", International Conference on Nuclear and Radiochemistry, Lindau, Oct. 8-12, 1984, paper No. 3.28 .

11. RYAN, J. L., BRAY, L. A., BOLDT, A. L.: "Dissolution of $\mathrm{PuO}_{2}$ or $\mathrm{NpO}_{2}$ using electroly tically regenerated reagents", Europ. Pat. Appl. No. 0089185 (1983). - BRAY, L. A., RYAN, J. L., "Catalyzed electroly tic dissolution of plutonium dioxide", in: J. D. NAVRATIL, W. W. SCHULZ, A. E. TALBOT (eds.), Actinide Recovery from Waste and Low. Grade Sources, p. 129, Harwood Academic Publishers, ChurLondon-New York 1981.

12. STOLL, W.: "Chemical and technological aspects of fast breeder fuel element fabrication", in: 1 . BAUMG ÄRTNER, K. EBERT, E. GELFORT, K. H. LIESER (eds.), Nukleare Entsorgung / Nuclear Fuel Cycle Vol. 2, p. 55, Verlag Chemie, Weinheim 1983.

13. PARKINSON, N., NELSON, R. L., KENT, W. C. L.: Nucl. Energy 20, 55 (1981).

14. OSHIMA, H., TAMURA, T., KOIZUMI, M.: "Outline of the conversion facility of $\mathrm{Pu}-\mathrm{U}$ nitrate solution to the mixed ox- ide using microwave heating", Trans. 3rd ENS Conf. 1982, p. 48.

15. BLANK, H.: "In-pile behaviour of nuclear fuels and irradiation targets", in G. KOCH, Transuranium Elements, Part A 2, p. 259. Gmelin Handbook of Inorganic Chemistry, Verlag Chemie, Weinheim 1973.

16. HENRICH, E., HÜFNER, R., SAHM, A.: "Improved procedures for efficient iodine removal from the dissolver solution", IAEA-SM-245/16 (1980).

17. HENRICH, E., HÜFNER, R.: "Modular design of a dissolver off-gas system", IAEA-CN-43/447 (1983).

18. HÜBSCHMANN, W., KIEFER, H., LEICHSENRING, C. H.: "Kosten-Nutzen-Analyse der $\mathrm{Kr}-85$-Rückhaltung in einer Kernbrennstoff-Wiederaufarbeitungsanlage", German Report KFK-3044 (1980).

19. HENRICH, E, HÜFNER, R., WEIRICH, F., BUMILLER, W., WOLFF, A.: "Selective absorption of noble gases in Freon12 at low temperatures and atmospheric pressure", 18 th DOE Nuclear Airborne Waste Management and Air Cleaning Conf., Baltimore, Md., Aug. 13-16, 1984, paper No. 14.3.

20. SCHMIEDER, H, COMPER, W, GOLDACKER, H., LEISTIKOW, S., PÖTZSCHKE, M., SATTLER, H. P.: "Hafnium für die Kritikalitätssicherheit bei der Kernbrennstoffverarbeitung", German Report KFK 2940 (1980), p. 144.

21. ERBEN, W., BESTANPOURI, A., DROSTE, R., MARX, G.: "Radiochemical studies of the corrosion of metals relevant to the PUREX process under the special influence of plutonium", Internat. Conf. on Nuclear and Radiochemistry, Lindau, Oct. $8-12,1984$, paper No. 3.42 .

22. SCHMIEDER, H., BLEYL, H. J., EBERT, K., HEILGEIST, M., KOLARIK, Z.: "Möglichkeiten zur Vereinfachung des Wiederaufarbeitungsverfahrens", Seminar on New Developments in Fuel Reprocessing, Obertraun (Austria), March 4-10, 1984.

23. PETRICH, G.: "Computer Simulation of the PUREX Process", in $F$. BAUMG ARTNER, K. EBERT, E. GELFORT, K. H. LIESER (eds.), Nukleare Entsorgung Vol. 2, p. 317, Verlag Chemie, Weinheim 1983.

24. HENRICH, E, BAUDER, U., DRUCKENBRODT, W. G., WITTMANN, K.: "Nichtextrak tive Feinreinigungszyklen für U und Pu im PUREX-ProzeB", Seminar on New Developments in Fuel Reprocessing, Obertraun (Austria), March 4-10, 1984.

25. RAINEY, R. H.: unpublished internal report, KfK, 1984.

26. KLEYKAMP, H.: "The composition of residues arising from the dissolution of irradiated fast breeder mixed oxide fuel", in: F. BAUMGARTNER, K. EBERT, E. GELFORT, K. H. LIESER (eds.), Nukleare Entsorgung, Vol. 2, p. 151, Verlag Chemie, Weinheim 1983. 